\title{
Changes in the plasma concentrations of free and conjugated oestrogens in heifers after treatment to induce superovulation and the relationship with number of ovulations
}

\author{
J. Saumande and A. Lopez-Sebastian* \\ I.N.R.A.-Station de Physiologie de la Reproduction, 37380 Nouzilly, France
}

\begin{abstract}
Summary. Oestradiol-17 $\beta$ and conjugated oestrone, oestradiol-17 $\beta$ and oestradiol$17 \alpha$ were measured in peripheral plasma of heifers treated with PMSG/PGF- $2 \alpha$ to induce superovulation.

Changes in the concentration of each hormone were synchronous, the highest level being near oestrus. For a given number of ovulations the hormone with the highest concentration was total oestradiol-17 $\alpha$, then came total oestrone, total oestradiol-17 $\beta$ and oestradiol-17 $\beta$. For each oestrogen, the maximum preovulatory concentration measured was significantly correlated with the number of ovulations; the regression line for total oestradiol-17 $\alpha$ was twice as steep as that for oestradiol- $17 \beta$.

It is concluded that in animals treated to induce superovulation assay of total oestradiol-17 $\alpha$ gives a better indication of the number of follicles induced to ovulate than does the more conventional assay of oestradiol- $17 \beta$.
\end{abstract}

\section{Introduction}

In the cow, preovulatory follicular growth can be followed quantitatively and qualitatively by assaying oestradiol-17 $\beta$ in peripheral blood (Saumande, 1978). Unfortunately, this method has two limitations: samples must be taken very frequently (every 2 or $3 \mathrm{~h}$ ) and the assay technique must be very sensitive because the concentration of hormone is less than $20 \mathrm{pg} / \mathrm{ml}$ (Henricks, Dickey \& Hill, 1971; Glencross, Munro, Senior \& Pope, 1973; Dobson \& Dean, 1974; Lemon \& Saumande, 1974; Chenault, Thatcher, Kalra, Abrams \& Wilcox, 1975; Peterson, Fairclough, Payne \& Smith, 1975; Thibier \& Saumande, 1975). In women, measurement of plasma oestrone sulphate concentrations gives the same information as oestradiol-17 $\beta$ values and is much easier to carry out because the concentration and the relative increase is much greater at the time of the preovulatory peak (Brown \& Smyth, 1971; Loriaux, Ruder \& Lipsett, 1971; Hawkins \& Oakey, 1974; Nuñez, Aedo, Landgren, Cekan \& Diczfalusy, 1977). For this reason we have attempted to assay conjugated oestrogens in the cow. Preliminary results have been disappointing: concentrations of conjugated oestrone are 10 times higher than those of the unbound form but there is no preovulatory increase and there is practically no conjugated oestradiol-17 $\beta$ or oestradiol-17 $\alpha$ (Lopez-Sebastian \& Saumande, 1979).

We present in this paper work which was undertaken with heifers that received a stimulant to follicular growth to test the hypothesis that this extreme model would show more clearly phenomena which are not apparent in normally cyclic animals.

* Present address: I.N.I.A.-C.R.I.D.A. 06, Avenida Puerta de Hierro, S/N Madrid 03, Spain. 


\section{Materials and Methods}

\section{Animals and treatments}

For this work 9 Friesian heifers were induced to superovulate by treatment with an intramuscular injection of 1200 to 2400 i.u. PMSG (Organon Oss, Netherlands) during the luteal phase, followed $48 \mathrm{~h}$ later by an intramuscular injection of $500 \mu \mathrm{g}$ prostaglandin F- $2 \alpha$ analogue (Estrumate: ICI, Cheshire, U.K.) to induce luteolysis (Hill, Dickey \& Henricks, 1973; Elsden, Lewis, Cumming \& Lawson, 1974). Blood samples were taken every $2 \mathrm{~h}$ from the time of injection of PMSG until $24 \mathrm{~h}$ after the beginning of oestrus. The blood was centrifuged immediately and the plasma was stored at $-15^{\circ} \mathrm{C}$ until it was assayed. Oestrus was detected by using a vasectomized bull twice daily. The number of ovulations was determined by counting the corpora lutea (CL) after lateral laparotomy 8-10 days after oestrus; this method allows the accurate determination of the number of CL up to 12-15 per ovary (Mariana, 1969).

\section{Assay techniques}

The concentration of oestradiol-17 $\beta$ was measured by the radioimmunoassay technique of Thibier \& Saumande (1975) with some modifications (Saumande, 1981). The assay was carried out directly after extraction because of the high specificity of the antibody. Free and bound fractions were separated by immunoprecipitation. The mean \pm s.d. recovery was $80.4 \pm 1 \cdot 2 \%$ $(n=100)$. The sensitivity of the method is $2 \mathrm{pg} / \mathrm{ml}$ and water blanks had lower values than this. The intra- and inter-assay variations were $5 \cdot 3 \%(n=6)$ and $10 \cdot 6 \%(n=17)$ respectively for a sample of pooled plasma from a PMSG-stimulated cow with a mean value of $35 \mathrm{pg} / \mathrm{ml}$.

Conjugated oestrogens were assayed by the method developed by Lopez-Sebastian \& Saumande (1979). Oestrone, oestradiol-17 $\beta$ and oestradiol-17 $\alpha$ were measured from the same sample of plasma after enzymic hydrolysis by Helix pomatia juice. Since the free and conjugated forms are not separated before hydrolysis we have assayed total oesterone, total oestradiol-17 $\beta$ and total oestradiol-17 $\alpha$. After ether extraction oestrone was separated from the two oestradiols on a Sephadex LH20 microcolumn. The oestradiol fraction was submitted to oxidation specific for the $17 \beta$-ol part after a second chromatography. Oestradiol-17 $\alpha$ was thus separated from the oestradiol-17 $\beta$ which was transformed to oestrone. Each oestrogen was then measured separately by radioimmunoassay. The antiserum used for the assay of oestrone did not show any cross-reaction higher than $1 \%$ with other oestrogens. For determination of oestradiol-17, the antiserum was produced against oestrone. It strongly cross-reacts with oestrone and oestradiol-17 $\beta$ but these were removed before the assay. The specificity of the assay was confirmed by the fact that the concentrations measured were independent of the volume of plasma. For total oestrone, oestradiol- $17 \beta$ and oestradiol-17 $\alpha$, recoveries were $79.4 \pm 4 \cdot 4,40 \cdot 1$ \pm 4.3 and $33.1 \pm 1 \cdot 3$ ( $n=20$ for each oestrogen), sensitivities were 5,9 and $11 \mathrm{pg} / \mathrm{ml}$ (expressed as unconjugated oestrogens) and the coefficients of variation were $6.1,7.0$ and $21 \cdot 6 \%(n=4$, concentration of oestrogens $17 \cdot 8,23 \cdot 0,34 \cdot 5 \mathrm{pg} / \mathrm{ml})$, respectively.

\section{Results}

With one exception the heifers were observed in oestrus $48 \mathrm{~h}$ after injection of PGF-2 $\alpha$. The number of ovulations induced varied from 1 to 27 (Table 1).

A comparison of the plots for the different conjugated oestrogens and for oestradiol-17 $\beta$ in one animal (Text-fig. 1) demonstrated that the pattern was similar for all oestrogens and the maximum value for each occurred just before oestrus. Quantitatively, the relative concentration of each oestrogen remained the same throughout the period of observation: the descending order of proportion was total oestradiol-17 $\alpha$, total oestrone, total oestradiol-17 $\beta$ and oestradiol-17 $\beta$. 
Table 1. Appearance of oestrus and number of ovulations in the treated heifers

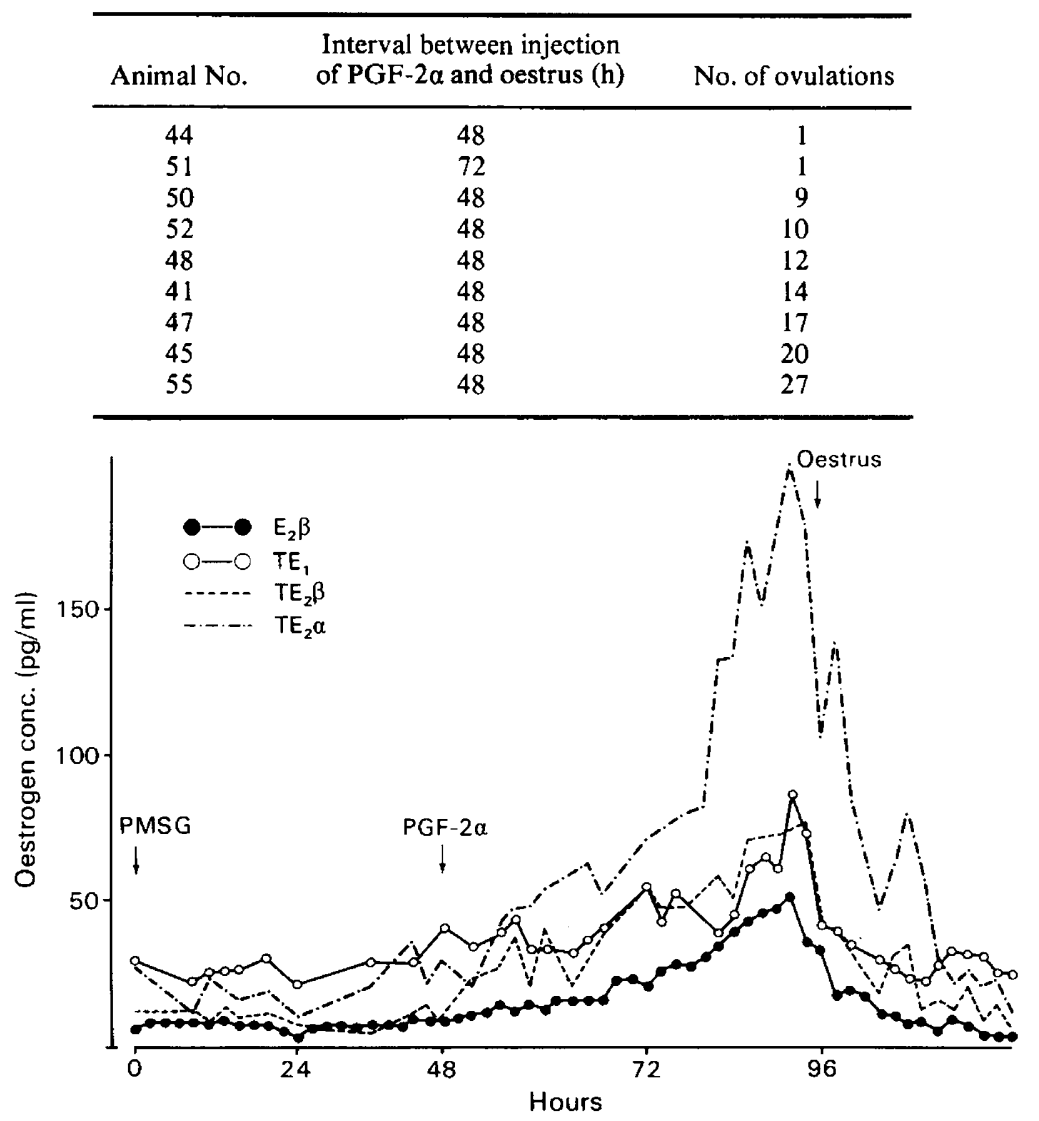

Text-fig. 1. Changes in plasma concentrations of oestradiol-17 $\beta\left(E_{2} \beta\right)$, total oestrone $\left(E_{1}\right)$, total

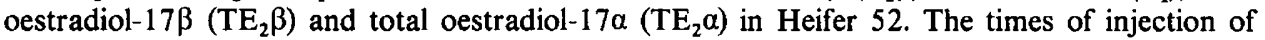
PMSG, injection of prostaglandin F-2 $\alpha$ and beginning of oestrus are indicated.

The maximum concentration of oestrogens depended on the number of follicles that ovulated and was affected neither by the dose of PMSG, the day of injection nor the number of large follicles appearing after ovulation (Henricks \& Hill, 1978; Saumande, 1978). The results obtained on all animals were therefore pooled and the correlation between the maximum concentrations of oestrogens and ovulation rate was examined (Table 2). All correlations were

Table 2. Relationship between the number of ovulations and the maximal concentration of different oestrogens in heifers

\begin{tabular}{|c|c|c|c|}
\hline \multirow[b]{2}{*}{ Oestrogen } & \multirow[b]{2}{*}{ Correlation coefficient } & \multicolumn{2}{|c|}{ Regression line } \\
\hline & & $\begin{array}{l}\text { Slope } \\
(b)\end{array}$ & $\begin{array}{l}\text { Intercept } \\
\text { with } y \text { axis } \\
\quad(a)\end{array}$ \\
\hline Oestradiol-17 $\beta$ & $0.95(P<0.01)$ & 5.975 & $12 \cdot 31$ \\
\hline Total oestrone & $0.71(P<0.05)$ & 3.491 & 33.66 \\
\hline Total oestradiol-17 $\beta$ & $0.71(P<0.05)$ & $9 \cdot 142$ & $32 \cdot 59$ \\
\hline Total oestradiol-17 $\alpha$ & $0.81(P<0.02)$ & 11.408 & 74.68 \\
\hline Total oestradiol- $17 \alpha+$ total oestradiol- $17 \beta$ & $0.80(P<0.01)$ & $20 \cdot 846$ & 101.09 \\
\hline Total oestrone, oestradiol- $17 \beta$ and oestradiol- $17 \alpha$ & $0.80(P<0.01)$ & 24.096 & 129.48 \\
\hline
\end{tabular}




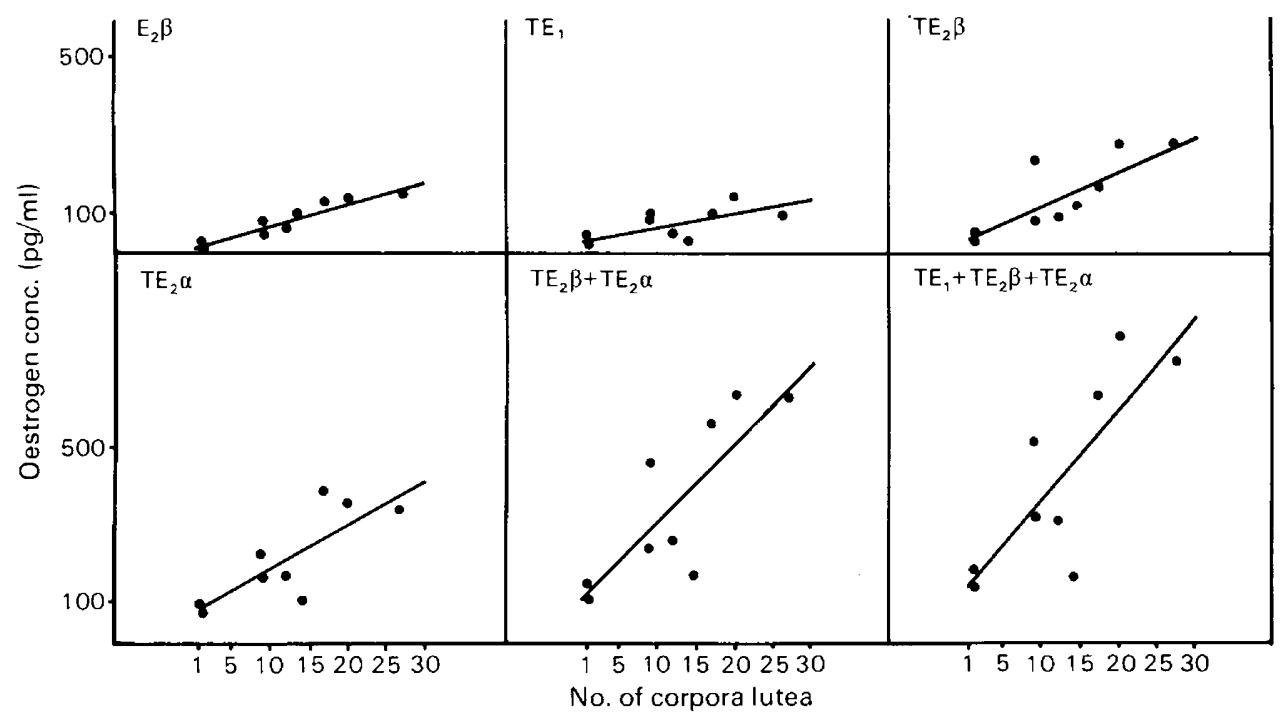

Text-fig. 2. Regression lines between the number of corpora lutea (presumed ovulations) and the maximal concentration of oestradiol- $17 \beta\left(E_{2} \beta\right)$, total oestrone $\left(\mathrm{TE}_{1}\right)$, total oestradiol-17 $\beta\left(\mathrm{TE}_{2} \beta\right)$, total oestradiol-17 $\alpha\left(\mathrm{TE}_{2} \alpha\right), \mathrm{TE}_{2} \beta+\mathrm{TE}_{2} \alpha$ and $\mathrm{TE}_{1}+\mathrm{TE}_{2} \beta+\mathrm{TE}_{2} \alpha$.

positive and significant, the most precise being with oestradiol-17 $\beta$. Comparison of the corresponding slopes of the lines showed that the total oestradiol-17 $\alpha$ slope was almost twice that of oestradiol-17ß (Text-fig. 2).

\section{Discussion}

The object of this work, like that in the cyclic cow, was to determine whether measuring one or more conjugated oestrogens as a guide to preovulatory follicular growth would be easier than, but just as precise as, measuring non-conjugated oestradiol-17 $\beta$ (Lemon \& Saumande, 1972; Saumande \& Pelletier, 1975; Saumande, 1980). In the cyclic animal we have already shown that assay of these three conjugated oestrogens does not improve the information obtained from measurement of oestradiol-17 $\beta$, nor does it remove any of the constraints attached to the assay of this hormone. By contrast, in heifers in which follicular growth was stimulated by PMSG the measurement of total oestradiol-17 $\alpha$ or perhaps total oestradiol-17 $\alpha$ plus total oestradiol-17 $\beta$ could be useful because the preovulatory rise in the level of these hormones is twice that observed with oestradiol-17 $\beta$.

Although the correlation coefficients between the number of ovulations and the maximal concentrations of total oestradiol- $17 \alpha$ or total oestradiol-17 $\alpha+$ total oestradiol-17 $\beta$ are lower than that for oestradiol-17 $\beta$, this could be due simply to a difference in precision of the assay method. The coefficients of variation are $20 \%$ and $9 \%$ for the assay of total oestradiol-17 $\alpha$ and oestradiol-17 $\beta$ (see 'Materials and Methods'). This technical problem can be overcome once an assay is developed exclusively for total oestradiol-17 $\alpha$.

We have thus come to conflicting conclusions depending on whether the animals have been treated to stimulate follicular growth. The reasons why animals treated with PMSG have a higher rise in conjugated oestrogens than oestradiol- $17 \beta$ compared with normal, cyclic animals are not clear. If, as in women, conjugated oestrogens are not secreted but are simply metabolites (Longcope, 1972; Ruder, Loriaux \& Lipsett. 1972), then we can predict that the difference in cows is due to a longer half life of the conjugated oestrogens than the free form (Sandberg, 
Gurpide \& Lieberman, 1964; Longcope, 1972; Ruder et al., 1972), resulting in an accumulation of conjugated oestrogens.

When considering the different concentrations of the 3 oestrogens and their relationship with follicular growth it should be remembered that oestradiol-17 $\alpha$ is not synthesized by the ovary (Short, 1962) but comes from transformation of oestradiol-17 $\beta$, particularly in the red blood cells (Axelrod \& Werthessen, 1960; Lunaas \& Velle, 1960; Velle, 1963). Moreover, during the cycle no changes in the concentration of oestradiol-17 $\alpha$ associated with the growth of follicles has been observed (Dobson \& Dean, 1974; Lopez-Sebastian \& Saumande, 1979).

Our results suggest that it may be possible to predict the number of ovulations from the maximum concentration of oestrogens. From a physiological point of view the results are difficult to explain in the light of our present knowledge of the synthesis and metabolism of oestrogens in the cow. From a practical point of view we suggest that, to follow the preovulatory growth of follicles in animals treated to induce superovulation, assay of total oestradiol-17 $\alpha$ could be a better and simpler method than the assay of oestradiol-17 $\beta$. Measurement of total oestradiol-17 $\alpha$ + total oestradiol- $17 \beta$ would be better than measuring total oestradiol-17 $\alpha$ alone because the correlation coefficients are comparable and the regression line is almost twice as steep.

\section{References}

Axeirod, L.R. \& Werthessen, N.T. (1960) The metabolism of estrone- $16^{14} \mathrm{C}$ in bovine blood. Archs Biochem. Biophys. 86, 53-55.

Brown, J.B. \& Smyth, B.J. (1971) Oestrone sulphatethe major circulating oestrogen in the normal menstrual cycle? J. Reprod. Fert. 24, 142, Abstr.

Chenault, J.R., Thatcher, W.W., Kalra, P.S., Abrams, R.M. \& Wilcox, C.J. (1975) Transitory changes in plasma progestins, estradiol and luteinizing hormone approaching ovulation in the bovine. J. Dairy $\mathrm{Sci}$. 58, 709-717.

Dobson, H. \& Dean, P.D.G. (1974) Radioimmunoassay of oestrone, oestradiol-17 $\alpha$ and $-17 \beta$ in bovine plasma during the oestrous cycle and last stages of pregnancy. J. Endocr. 61, 479-486.

Elsden, R.P., Lewis, S., Cumming, I.A. \& Lawson, R.A.S. (1974) Superovulation in the cow following treatment with PMSG and prostaglandin $\mathrm{F}_{2 \alpha} . J$. Reprod. Fert. 36, 455-456, Abstr.

Glencross, R.G., Munro, I.B., Senior, B.E. \& Pope, G.S. (1973) Concentrations of $17 \beta$-oestradiol, oestrone and progesterone in jugular venous plasma of cows during the oestrous cycle and in early pregnancy. Acta endocr., Copenh. 73, 374-384.

Hawkins, R.A. \& Oakey, R.E. (1974) Estimation of oestrone sulphate, oestradiol-17 $\beta$ and oestrone in peripheral plasma: concentrations during the menstrual cycle and in men. J. Endocr. 60, 3-17.

Henricks, D.M. \& Hill, J.R. (1978) Effects of PMSG and $\mathrm{PGF}_{2 \alpha}$ on gonadal hormones and reproduction in the beef heifer. J. Anim. Sci. 46, 1309-1315.

Henricks, D.M., Dickey, J.F. \& Hill, J.R. (1971) Plasma estrogen and progesterone levels in cows prior to and during estrus. Endocrinology 89, 1350-1355.

Hill, J.R., Dickey, J.F. \& Henricks, D.M. (1973) Estrus and ovulation in $\mathrm{PGF}_{211} / \mathrm{PMS}$ treated heifers. $J$. Anim. Sci. 37, 315, Abstr.

Lemon, M. \& Saumande, J. (1972) Oestradiol-17 $\beta$ and progesterone after induction of superovulation in cattle. J. Reprod. Fert. 31, 501-502, Abstr.
Lemon, M. \& Saumande, J. (1974) The evolution of ovarian steroid hormones during luteolysis and folliculogenesis in the cow. Eur. J. Obstet. Gynec. Reprod. Biol. 4, S69-S75.

Longcope, C. (1972) The metabolism of estrone sulfate in normal males. J. clin. Endocr. Metab. 34, $113-122$.

Lopez-Sebastian, A. \& Saumande, J. (1979) Dosage des oestrogènes libres et conjugués dans le plasma périphérique de vache cyclique. Annls Biol. anim. Biochim. Biophys. 19, 1689-1699.

Loriaux, D.L., Ruder, H.J. \& Lipsett, M.B. (1971) The measurement of estrone sulfate in plasma. Steroids $18,463-472$.

Lunaas, T. \& Velle, W. (1960) Estrogen metabolism in vitro in the presence of mammalian erythrocytes. A comparative study. Acta physiol. scand., Suppl. 175, 95-97.

Mariana, J.C. (1969) Technique d'examen in vivo des ovaires chez la veche. Annls Biol. anim. Biochim. Biophys. 9, 657-659.

Nuñez, M., Aedo, A.R., Landgren, B.M., Cekan, S.Z. \& Diczfalusy, E. (1977) Studies on the pattern of circulating steroids in the normal menstrual cycle. 6 . Levels of oestrone sulphate and oestradiol sulphate. Acta endocr., Copenh. 86, 621-633.

Peterson, A.J., Fairclough, R.J., Payne, E. \& Smith, J.F. (1975) Hormonal changes around bovine luteolysis. Prostaglandins 10, 675-684.

Ruder, H.J., Loriaux, L. \& Lipsett, M.B. (1972) Estrone sulfate: production rate and metabolism in man. $J$. clin. Invest. 51, 1020-1033.

Sandberg, E., Gurpide, E. \& Lieberman, S. (1964) Quantitative studies on the metabolism of dehydroisoandrosterone sulfate. Biochemistry, N.Y. 3, 12561267.

Saumande, J. (1978) Relationships between ovarian stimulation by PMSG and steroid secretion. In Control of Reproduction in the Cow, pp. 169-194. Ed. J. M. Sreenan. Martinus Nijhoff, The Hague. 
Saumande, J. (1980) Concentrations of luteinizing hormone, oestradiol-17 $\beta$ and progesterone in the plasma of heifers treated to induce superovulation. $J$. Endocr. 84, 425-437.

Saumande, J. (1981) Radioimmunoassay of estradiol$17 \beta$ in unextracted plasma. Steroids 38, 425-437.

Saumande, J. \& Pelletier, J. (1975) Relationship of plasma levels of oestradiol-17 $\beta$ and luteinizing hormone with ovulation rate in superovulated cattle. J. Endocr. 64, 189-190.
Short, R.V. (1962) Steroid concentrations in normal follicular fluid and ovarian cyst fluid from cows. $J$. Reprod. Fert. 4, 27-45.

Thibier, M. \& Saumande, J. (1975) Oestradiol-17ß, progesterone and $17 \alpha$-hydroxyprogesterone concentrations in jugular venous plasma in cows prior to and during oestrus. J. Steroid Biochem. 6, 14331437.

Velle, W. (1963) Metabolism of oestrogenic hormones in domestic animals. Gen. comp. Endocr. 3, 621-635.

Received 28 October 1981 